\title{
Features of the Pension System, the Impact on the Level, Quality, and Life Expectancy
}

\section{IBRAGIMOVA Guliya Magdutovna ${ }^{1}$, GERKINA Elena Aleksandrovna ${ }^{2}$, YAKUPOVA Dayana Andreevna ${ }^{3}$}

\author{
${ }^{I}$ Kazan Federal University (KAZAKISTAN) \\ ${ }^{2}$ Kazan Federal University (KAZAKISTAN) \\ ${ }^{3}$ Kazan Federal University (KAZAKISTAN) \\ Email: guliyk@yandex.ru
}

\begin{abstract}
Each pension system is unique, despite their common goal. Any state forms or does not form its own pension system depending on many factors, and the structure and methods of introducing this system into the real life of citizens differ radically from state to state. The pension system is an essential part of the social support of the population. The idea of a pension system is necessary as a solution to the problem of providing means of life for people in old age when they cease to receive income from labor activity. Thus, the core of the pension system, as a rule, is a labor pension, which performs the function of transferring people's income from the able-bodied stage of life to the period when a person loses his ability to work. Therefore, a pension is, first of all, social compensation to someone who cannot receive a salary due to reaching retirement age and leaving the labor market. However, this is not the end of the social function of the pension - it should provide not only necessary but also decent living conditions for those who did not receive high salaries and were unable to earn a large pension [2].
\end{abstract}

Keywords: pension system, quality of life, life expectancy, health care, healthy lifestyle, retirement age

JEL: M20

UDK: 364.35

330.59

\section{Introduction}

Pension support is understood as a form of material support of citizens by the state [8]. The grounds for its receipt are determined by the legislative framework of the country. Note that they vary for each state due to their own characteristics. The pension system is formed and operates also on the basis of the characteristic features of the economic and social situation and the life of the country's population [9]. And the activity and condition of the society older people live in largely depends on the regulation of the pension system.

Pension systems have two main objectives: reducing the poverty level of citizens in old age and replacing income or smoothing consumption. The first objective, as a rule, is provided by state pension systems financed on the pay-as-you-go basis (PAYG) from targeted contributions or from general incomes. The second objective of the pension system is to maintain more or less the same standard of living for all after retirement, which can be achieved through the PAYG system or the funded pension system. 


\section{Methods}

The contributory pension system implies investment of pension contributions and payment of benefits out of accumulated savings. Accumulative pension systems are often called private. Indeed, the state pension systems of most OECD countries are funded by the insurance part, while private systems are contributory. However, contributory pension systems can also be regulated by the state, which partially relates to the Russian Federation. In order to evaluate pension systems, it is necessary to consider these two systems (the PAYG system in comparison with the contributory system, the state system in comparison with the private one) separately.

Multiple theoretical and empirical studies have been conducted on the impact of funded pension systems on households and national savings. An empirical study is essentially an inconclusive assumption regarding the mandatory funded pension system, which, in general, can contribute to the growth of national savings.

Contributory pension systems can also contribute to economic development through other instruments - they can reduce the distortion of employment and the number of constraints to increase savings through contributions to social insurance funds [7]. They can also facilitate long-term investments in important areas such as infrastructure. Moreover, they can increase the efficiency and level of financial intermediation, improving the prospects for economic growth.

\section{Results and Discussion}

Pension systems have two main objectives: reducing the poverty level of citizens in old age and replacing income or smoothing consumption. The first objective, as a rule, is provided by state pension systems financed on the pay-as-you-go basis (PAYG) from targeted contributions or from general incomes. The second objective of the pension system is to maintain more or less the same standard of living for all after retirement, which can be achieved through the PAYG system or the funded pension system.

The contributory pension system implies investment of pension contributions and payment of benefits out of accumulated savings [6]. Accumulative pension systems are often called private. Indeed, the state pension systems of most OECD countries are funded by the insurance part, while private systems are contributory. However, contributory pension systems can also be regulated by the state, which partially relates to the Russian Federation. In order to evaluate pension systems, it is necessary to consider these two systems (the PAYG system in comparison with the contributory system, the state system in comparison with the private one) separately.

Multiple theoretical and empirical studies have been conducted on the impact of funded pension systems on households and national savings. An empirical study is essentially an inconclusive assumption regarding the mandatory funded pension system, which, in general, can contribute to the growth of national savings.

Contributory pension systems can also contribute to economic development through other instruments - they can reduce the distortion of employment and the number of constraints to increase savings through contributions to social insurance funds. They can also facilitate longterm investments in important areas such as infrastructure. Moreover, they can increase the efficiency and level of financial intermediation, improving the prospects for economic growth.

There are three main channels of the influence of contributory pension systems on financial development:

1. Direct changes in the system of contributory pensions, as well as in the size and composition of the financial system as a result of the transfer of mandatory pension 
payments from PAYG to the contributory pension system. Pension reform can affect the volume of savings in the economy and, as a result, lead to a change in the level of financial intermediation.

2. A direct effect on financial intermediation should also be expected. If the transition from AYG to the contributory system occurs through the issuance of government debt, market capitalization will increase and, possibly, the maturity of government debt will increase. The development of the public debt market can, in turn, stimulate the growth of the market for non-equity securities.

3. Changes in the effectiveness and composition of financial intermediation as a result of the emergence of pension funds and other institutional investors. Certain improvements in the financial system may be the result of regulatory reform, as well as the work of pension funds and other institutional investors participating in the new contributory system.

Pension funds and other institutional investors can have a secondary effect on the composition of the financial system, for example, by increasing the time for fulfilling obligations on corporate and private loans. They can also increase the effectiveness of financial intermediation, for example, by increasing the liquidity of securities markets and acting as a counterweight to the powers exercised by banks. They can thus contribute to a better allocation of resources and improve economic performance [10].

\section{Summary}

Pension systems of different countries have their own distinctive features determined by various factors, such as the country's history, political situation, the regime of government, etc. Identification of the advantages and disadvantages of a particular pension system is necessary as it helps adopt the positive experience of other countries, thereby improving the domestic system. In order for the standard of living of the population to grow and other important criteria for the well-being of citizens to be at a decent level, it is necessary to constantly improve the country's pension system, which must be flexible and primarily socially oriented.

In order to examine and analyze the similarities and differences in more detail, as well as to identify the features of approaches to this issue in the Russian Federation and a number of other countries, we will use the Global Retirement Index data. Based on data from the World Bank and official statistics of 43 countries, the rating shows certain parameters of the life of pensioners: from the possibility of finding a job to the availability of medical services.

The index rating included 43 countries: all OECD participants, countries with advanced economies in terms of the IMF, and members of the BRICS group (Brazil, Russia, India, China, and South Africa).

In 2018, Global Pension Index underwent a number of changes. Switzerland became the leading country (previously this position belonged to Norway). It is worth noting that Switzerland entered the top ten in all four groups of index indicators. Norway fell in the ranking due to a sharp decline in its financial performance. Top 5 also includes Sweden and New Zealand [5].

The rating takes into account 18 indicators estimated from 0 to $100 \%$ and classified into 4 groups:

- material well-being (level of economic inequality, median salary, unemployment rate);

- health care (life expectancy, public health expenditures per capita, health insurance costs);

- quality of life (satisfaction with life, level of air pollution, water quality and sanitary conditions, biological diversity and habitat, environment); 
- financial condition (the share of pensioners in relation to the working population, nonrepayable bank loans, inflation, interest rate, tax burden, government, level of public debt) [5].

The authors of the rating identified 5 key threats to future retirement benefits:

- monetary policy (constantly in crisis),

- growing public debt,

- an increase in the number of elderly people,

- climate changes,

- a decrease in the quality of life of pensioners (namely, a high level of unemployment and an increase in health care costs).

In comparison with 2017, in 2018, for a number of indicators, the Russian Federation worsened its position in the ranking. For example, in terms of the quality of life of pensioners, it fell from $36^{\text {th }}$ to $38^{\text {th }}$ position. It should be noted that the reason was environmental degradation (position in the ranking of countries, $3^{\text {rd }}$ place from the end), biodiversity (rating 6 from the end), and level of happiness (rating 9 from the end) [5].

The health sector: in this group of indicators, the Russian Federation is in the penultimate, $42^{\text {nd }}$ place. In terms of expenses for insurance medicine, Russia ranks fourth from the end, and second from the end in the rating for life expectancy [4].

Over the past three years, Russia has shown steady progress in financial performance. In particular, according to the authors of the index, the situation with interest rate and tax pressure has significantly improved in Russia ( $12^{\text {th }}$ place). In addition, the country ranked second in the world in terms of the low level of public debt. However, it is worth noting that the financial condition of pensioners in this group of indicators takes the last $43^{\text {rd }}$ place.

Russia is also a world outsider in the field of public administration and ranks sixth from the end in terms of troubled bank loans [1].

Nevertheless, Russia has made the greatest progress in the sphere of material well-being of pensioners. According to this group of indicators, the country takes $30^{\text {th }}$ place in the world, improving the situation with employment and income equality. At the same time, the level of per capita income continues to decline - the country is in fifth place from the bottom.

The most favorable situation in Russia with a demographic load factor is $11^{\text {th }}$ in the world by this indicator (however, the share of pensioners in relation to the working population continues to grow).

Another indicator Russia almost equals the most developed countries in is the level of gross national income (GNI) per capita. In Russia, it is above the global average.

The current pension system is built on the principle of redistribution of funds between generations. It is called pay-as-you-go. But, probably, it should also be called "receive while you live". The world goes through a process of population aging - everyone knows and sees it. People do not die from old age but from age-related diseases, and from this point of view, a huge amount of resources is being invested in the search for cures for aging, in the study of the mechanisms of aging, and the fight against them. What is this going to lead to? To the increase in life expectancy. Thus, the invention of penicillin and a number of drugs in the XX century led to an increase in life expectancy. Accordingly, it is necessary to talk not only about increasing life expectancy but also about increasing the duration of a healthy life.

\section{Conclusions}

Pension reform needs to be discussed with an assessment of the possible social consequences. First of all, from the standpoint of the influence of possible transformations on overcoming poverty in our country, which is one of the main priorities of the current presidential cycle [3]. 
The results of the rating show a very large gap between the provisions of countries, which is justified by four criteria for the quality of life of pensioners. Also, according to the above data, one can trace both the position of countries in the overall ranking and for each of the evaluated criteria. Such a significant gap between the countries is caused, first of all, by the state of health of pensioners and the presence of a favorable environment for them, as we see these criteria in the most adverse condition. Also, Russia takes a non-competing position in relation to European countries in terms of material security of pensioners. This index clearly demonstrates that many of the fundamental criteria necessary for the well-being of pensioners in Russia are not up to par and cannot compete with the advanced countries of Europe.

\section{Acknowledgments}

The work is performed according to the Russian Government Program of Competitive Growth of Kazan Federal University.

\section{REFERENCES}

1. Analytical materials. "Old people" over 45 or age discrimination https://careerist.ru/news/stariki-za45-ili-diskriminaciya-po-vozrastnomu-priznaku.html

2. Газета.ru. The right to work instead of the right to rest https://www.gazeta.ru/comments/2018/06/21_e_11809999.shtml?updated

3. Korovkin. Consequences of raising the retirement age for the labor market https://www.vedomosti.ru/management/blogs/2015/05/27/593847-ugrozi-povisheniya

4. Ruxpert. Natural population growth in Russia https://ruxpert.ru/Файл:Естественный_прирост_населения_России.jpg

5. Global AgeWatch Index 2018[Electronic resource]: HelpAge International. - Access mode: http://www.helpage.org/global-agewatch/population-ageing-data/global-rankings-table/

6. Afanasiev, S.A., Pension Reform in Russia: First Year of Implementing, Technical Report, 2003-03, Available at SSRN: http://hermes-ir.lib.hit-u.ac.jp/rs/bitstream/10086/14467/1/pie, February 22, 2003, in Russian.

7. B. Harsman and J.M. Quigley (eds), Government for the Future Unification, Fragmentation and Regionalism, Elsevier, Science BV, Amsterdam. Lim, J. and Ooi, B.J., 1998.

8. Enright M. J. Survey on the Characterization of Regional Clusters: Initial Results. Working Paper // Institute of Economic Policy and Business Strategy: Competitiveness Program University of Hong Kong. 2000, p. 21.

9. J. Stiglitz. Globalization and the economic role of the state in the new millennium //Industrial and Corporate Change. - 2003, Vol. 12, № 1, pp. 3-26.

10. Asher, M.G., 2001. "Reforming Singapore's Tax System for the $21^{\text {st }}$ Century” in Chng M. K., Hui W. T., Koh A. T., Lim K. L. and Bhanoji R. (eds) Singapore Economy in the $21^{\text {st }}$ Century: Issues and Strategies, Singapore: McGraw-Hill Book Co.

\section{Article history:}

- $\quad$ Received 25 September 2019

- Accepted 15 November 2019 